\title{
SOME DETAILS OF FOREST FIRE STATISTICS IN BRAZIL
}

\author{
Ronaldo Viana Soares ${ }^{1}$, Juliana Ferreira Santos ${ }^{2}$, Antonio Carlos Batista ${ }^{1}$ \\ ${ }^{1}$ Eng. Florestal, Dr., Depto. de Ciências Florestais, UFPR, Curitiba, PR, Brasil - rvsoares@ufpr.br - batistaufpr@ufpr.br \\ ${ }^{2}$ Eng. Florestal, M.Sc., SENAI, Curitiba, PR, Brasil - juliana.santos@pr.senai.br \\ Recebido para publicação: 29/07/2007 - Aceito para publicação: 20/10/2008
}

\begin{abstract}
The objective of this research was to answer some questions about forest fire occurrence in Brazil. A total of 19,377 fires were analyzed in the period 1998 - 2002. Tabulated data, in percentage, were transformed through $\sqrt{\mathrm{y}+1 / 2}$ and then submitted to the analysis of variance. The means were compared through the SNK test at 5\% significance level. Results showed significant differences both, in number of fires and burned areas along the months of the year. August was the month with higher number of fires, followed by July, October and September; August, September and November presented the highest burned areas. Significant differences were also detected among the group causes and along the daily hours. Incendiary was the leading cause, statistically different from the other groups, both in number of fires and burned area. About $69 \%$ of the fires, corresponding to $66 \%$ of the burned area occurred between 12 noon to 6:00 PM. Number of fires starting hourly, from 1:00 PM to 4:00 PM, didn't differ statistically among them, but were significantly different from the other daily hours. As for the burned areas, fires starting at 5:00 PM should be included in the previous group. No statistical difference was detected among the days of the week both, for the number of fires and the burned areas, showing that, on the contrary of the popular belief, fires don't preferentially occur during the weekends.

Keywords: Forest fire; fire statistics; forest protection.
\end{abstract}

\section{Resumo}

Algumas características dos incêndios florestais no Brasil. O objetivo deste trabalho foi responder a alguns questionamentos sobre as ocorrências de incêndios florestais em áreas protegidas no Brasil. Com base em questionários respondidos por empresas e instituições florestais, 19.377 incêndios que ocorreram no período de 1998 a 2002 foram analisados. Os resultados mostraram diferenças significativas tanto no número de ocorrências como nas superfícies atingidas pelo fogo, entre os meses do ano. Agosto foi o mês com o maior número de ocorrências, seguido por julho, outubro e setembro. Agosto, setembro e novembro apresentaram as maiores áreas queimadas. Diferenças significativas foram também observadas entre os grupos de causas e as horas do dia. $\mathrm{O}$ grupo "incendiários" liderou as estatísticas de causas, diferindo estatisticamente de todos os demais tanto em número de ocorrências como em área queimada. Cerca de $69 \%$ dos incêndios, correspondendo a $66 \%$ das áreas queimadas ocorreram entre as 12 e 18 horas. O número de incêndios iniciados entre 13 e 16 horas não diferiu estatisticamente entre si, mas foi significativamente superior às demais horas do dia. Com relação às áreas queimadas, os incêndios que começaram às 17 horas também devem ser incluídos no grupo anterior (13 a 16 horas). Não foram detectadas diferenças significativas entre os dias da semana, nem para o número de ocorrências nem para as áreas queimadas, o que desmente o mito popular de que os incêndios ocorrem preferencialmente nos fins de semana.

Palavras-chave: Incêndios florestais; estatísticas de incêndios; proteção florestal.

\section{INTRODUCTION}

Fire control efficiency can be improved if the forest manager has knowledge of some characteristics of fire occurrence in the forest district he supervises. Knowing the fire season extension allows the activation of the suppression forces when the danger is high and to reduce the preparedness during the months of low risk. Determination of the main causes will help to direct the prevention actions to reduce them. The knowledge of the higher risk hours of the day will permit the establishment of the 
lookout towers surveillance schedule. Another information that also can be useful is the distribution of fire occurrences through the weekdays. There is a belief among fire fighters that most fires occur during the weekend, but only a significant record of fire occurrences could prove if this is true or not.

According to Crosby (1954) the success in forest fire suppression depends mainly upon the speed and power of initial attack. The maintenance of an efficient system of fire control is quite expensive and therefore economically unacceptable to be active all year round. So, it is important to know the extension of the fire season and other aspects related to the fire occurrence.

The first paper dealing with fire statistics in Brazil was published in 1974 (SOARES e CORDEIRO 1974), based on recorded fires in the central region of Paraná State, from June1965 to May 1974. Only in 1984 the first paper showing fire statistics nationwide was published (SOARES, 1984), based on data collected in 1983. After that, several papers were published (SOARES 1988; SOARES 1989; SOARES; SANTOS 2002b; SANTOS 2004), always improving the data basis.

The objective of this paper was to carry out statistical analysis on some aspects of fire occurrence, such as monthly, hourly, and weekday distribution, and group causes, in order to establish the fire season extension, the time of the day and the day of week with higher occurrence percentages, and the main group cause.

\section{METHODS}

The database used to carry out this research was the information contained in the questionnaires, received from forest companies and other forest institutions that operate fire control systems and record the fire occurrences, in the period 1998-2002. Therefore, it is necessary to clarify that the data used in the research refers to protected areas from 9 (Amapá, Bahia, Espírito Santo, Minas Gerais, Pará, Paraná, Rio Grande do Sul, Santa Catarina, and São Paulo) of the 26 Brazilian States.

The questionnaires, accompanied of letters explaining the objectives and the importance of the project, were sent to forest companies, forest associations, national and state parks, regional IBAMA (Brazilian Forest Service) offices, state forest services, and similar institutions, in order to cover the broader possible universe of information generator organizations.

The information extracted from the questionnaires for this research were: $i$ ) date of occurrence; ii) burned area; iii) time of fire detection; and $i v$ ) probable fire cause.

\section{Monthly distribution}

The fire occurrences as well as the burned areas were distributed along the months of the year to establish the country's fire season.

\section{Hourly distribution}

The fire occurrences and the respective burned areas were also distributed along the hours of the day to establish the peak of fire starting.

\section{Distribution through the days of the week}

In order to answer to the question whether fires occur preferentially during the weekends, an analysis of the occurrences distribution through the days of the week was carried out.

\section{Probable causes}

The fires that had the probable causes identified were classified according to the following groups, as suggested by FAO (1954): i) Lightning; ii) Debris burnings; iii) Incendiary; iv) Smoking; v) Campfires; vi) Forest operations; vii) Railroad; viii) Miscellaneous. Fires that didn't have the cause identified were not included in the statistics.

\section{Statistical analysis}

To proceed the analysis of variance the months of the year, the daily hours, the days of the week, and the group causes were considered the treatments, and the years (5) of data collecting, the replications. Because the data utilized were expressed in percentages, with some low values and even zeros, the 
transformation by $\sqrt{\mathrm{y}+1 / 2}$ was used (STEEL; TORRIE 1960) and normal distribution tests were applied. Mean values were compared by the SNK procedure at 5\% significance level.

\section{RESULTS AND DISCUSSION}

The statistical analysis showed significant differences both, in the number of fire occurrences and in the burned areas, along the months of the year (Table 1). August was the month with higher number of fires in the studied period, followed by July, October and September. As for the burned areas, August, September and October didn't statistically differ among them, but were significantly different from all other months. The results suggest that the fire season in Brazil, in the period 1998-2002, extended from July to October, when almost $60 \%$ of the fires occurred, corresponding to nearly $90 \%$ of the burned area.

Table 1. Monthly fire occurrences and burned areas in the period 1998-2002.

Tabela 1. Distribuição mensal das ocorrências de incêndios e respectivas áreas queimadas no período 1998-2002.

\begin{tabular}{lcccc}
\hline \multirow{2}{*}{ Month } & \multicolumn{2}{c}{ Fires } & Burned areas \\
\cline { 2 - 5 } & $\mathbf{n}^{\circ}$ & $\boldsymbol{\%}^{*}$ & $\mathbf{\text { ha }}$ \\
\hline January & 875 & $4.52 \mathrm{cde}$ & 1100.96 & $1.28 \mathrm{~b}$ \\
February & 1343 & $6.93 \mathrm{cde}$ & 1407.69 & $1.64 \mathrm{~b}$ \\
March & 692 & $3.57 \mathrm{de}$ & 666.35 & $0.78 \mathrm{~b}$ \\
April & 901 & $4.65 \mathrm{de}$ & 802.66 & $0.94 \mathrm{~b}$ \\
May & 1166 & $6.02 \mathrm{cde}$ & 1061.20 & $1.24 \mathrm{~b}$ \\
June & 1893 & $9.77 \mathrm{bcd}$ & 1968.97 & $2.30 \mathrm{~b}$ \\
July & 2698 & $13.92 \mathrm{bc}$ & 5084.26 & $5.93 \mathrm{~b}$ \\
August & 4222 & $21.78 \mathrm{a}$ & 24228.58 & $28.25 \mathrm{a}$ \\
September & 2230 & $11.51 \mathrm{bcd}$ & 14881.93 & $17.36 \mathrm{a}$ \\
October & 2311 & $11.93 \mathrm{bc}$ & 31643.23 & $36.91 \mathrm{a}$ \\
November & 444 & $2.29 \mathrm{e}$ & 1296.34 & $1.51 \mathrm{~b}$ \\
December & 602 & $3.11 \mathrm{e}$ & 1592.85 & $1.86 \mathrm{~b}$ \\
\hline Total & 19377 & 100.00 & 85735.02 & 100.00 \\
\hline
\end{tabular}

* Means followed by the same letter are not statistically different by the SNK test at $5 \%$ level.

Soares; Cordeiro (1974) analyzing data from the State of Paraná, concluded that most fires and respective burned areas were recorded from July to December. Soares; Santos (2002a), based on data from Brazilian protected lands, in the period 1983-1997, suggested that the fire season in the country extended from July to November.

Data from table 2 shows that significant differences were observed in fire occurrence and burned areas during the hours of the day. Fires were recorded mainly from 1:00 to 4:00 PM (almost 45\% of the occurrences), whereas most of the areas were burned from 1:00 to 5:00 PM (more than 50\% of the affected areas). On the other hand, fires seldom occurred between midnight and 7:00 AM. Unpublished data from the Monte Alegre forest district, in the State of Paraná, showed that in 1982, a severe fire year, more than 79\% of the fires were recorded between 11:00 AM and 6:00 PM, and more than 96\% between 9:00 AM and 10:00 PM, period of the company lookout tower's operation.

Data presented in table 3 shows that although the number of fire occurrences on Sundays was a little higher than the other days, no statistical difference was detected. Regarding the burning areas, due to the great data variability, there were no significant differences among the days of the week. These results contradict a popular belief that says that fires occur mainly during the weekends.

Incendiaries were the main group of fire causes (Figure 1), significantly different from all others, and followed by Debris burning (Figure 2) and Miscellaneous. Lightning (Figure 3), the only natural cause was responsible for less than $2 \%$ of the reported fires. As for the burning areas, incendiaries were also the main group, followed by Debris burning. In the previous surveys on forest fires causes (SOARES 
e CORDEIRO 1974; SOARES 1984; SOARES 1989) the main cause was Debris burning. However, from 1994 on, Incendiaries became the leading cause of forest fires in Brazil (SOARES e SANTOS 2002b; SANTOS 2004). Unfortunately, this is a tendency observed in most parts of the world (SOARES 1997).

Table 2. Hourly distribution of fire occurrences and burned areas in the period 1998-2002.

Tabela 2. Distribuição das ocorrências de incêndios e áreas queimadas através das horas do dia no período 1998-2002.

\begin{tabular}{|c|c|c|c|c|}
\hline \multirow{2}{*}{ Dailytime } & \multicolumn{2}{|c|}{ Fires } & \multicolumn{2}{|c|}{ Burned areas } \\
\hline & $n^{0}$ & $\% *$ & ha & $\% *$ \\
\hline 01:00 & 74 & $0,44 \mathrm{ab}$ & 1061,99 & 2,64 abcd \\
\hline 02:00 & 38 & $0,23 \mathrm{a}$ & 747,34 & $1,86 \mathrm{abcd}$ \\
\hline 03:00 & 32 & $0,19 \mathrm{a}$ & 14,89 & $0,04 \mathrm{a}$ \\
\hline 04:00 & 44 & $0,26 \mathrm{a}$ & 56,84 & $0,14 \mathrm{a}$ \\
\hline 05:00 & 54 & $0,32 \mathrm{ab}$ & 70,30 & $0,18 \mathrm{a}$ \\
\hline 06:00 & 74 & $0,44 \mathrm{ab}$ & 277,11 & $0,69 \mathrm{ab}$ \\
\hline 07:00 & 128 & $0,76 \mathrm{abc}$ & 441,03 & $1,10 \mathrm{abc}$ \\
\hline 08:00 & 357 & $2,13 \mathrm{de}$ & 675,22 & $1,68 \mathrm{abcd}$ \\
\hline 09:00 & 452 & $2,70 \mathrm{e}$ & 958,24 & $2,39 \mathrm{abcd}$ \\
\hline 10:00 & 728 & $4,34 \mathrm{~g}$ & 1487,69 & 3,70 abcd \\
\hline 11:00 & 1000 & $5,96 \mathrm{~h}$ & 2220,33 & 5,53 defgh \\
\hline $12: 00$ & 1334 & $7,96 \mathrm{i}$ & 2337,08 & 5,82 defgh \\
\hline $13: 00$ & 1796 & $10,71 \mathrm{j}$ & 4884,76 & $12,16 \mathrm{hi}$ \\
\hline $14: 00$ & 1975 & $11,78 \mathrm{j}$ & 3863,97 & 9,62 fghi \\
\hline $15: 00$ & 1953 & $11,65 \mathrm{j}$ & 4926,28 & $12,26 \mathrm{hi}$ \\
\hline $16: 00$ & 1800 & $10,73 \mathrm{j}$ & 3437,21 & 8,56 efghi \\
\hline $17: 00$ & 1414 & $8,43 \mathrm{i}$ & 4203,24 & 10,46 ghi \\
\hline 18:00 & 1213 & 7,23 hi & 2884,70 & 7,18 defgh \\
\hline $19: 00$ & 772 & $4,60 \mathrm{fg}$ & 2711,62 & 6,75 defgh \\
\hline 20:00 & 570 & 3,40 ef & 1544,74 & 3,85 abcde \\
\hline $21: 00$ & 373 & $2,22 \mathrm{de}$ & 560,92 & 1,40 abcd \\
\hline 22:00 & 263 & $1,57 \mathrm{~cd}$ & 484,73 & $1,21 \mathrm{abcd}$ \\
\hline 23:00 & 193 & $1,15 \mathrm{bc}$ & 164,93 & $0,41 \mathrm{ab}$ \\
\hline 24:00 & 132 & $0,79 \mathrm{abc}$ & 151,33 & $0,38 \mathrm{ab}$ \\
\hline Total & 16769 & 100,00 & 40166,48 & 100,00 \\
\hline
\end{tabular}

* Means followed by the same letter are not statistically different by the SNK test at 5\% level.

Table 3. Weekly days distribution of fire occurrences and burned areas, from 1998 to 2002.

Tabela 3. Distribuição das ocorrências de incêndios e áreas queimadas através dos dias da semana no período 1998-2002.

\begin{tabular}{lcccc}
\hline \multirow{2}{*}{ Day of the week } & \multicolumn{2}{c}{ Fires } & \multicolumn{2}{c}{ Burned areas } \\
\cline { 2 - 5 } & $\mathbf{n}^{\mathbf{0}}$ & $\mathbf{\%}^{*}$ & ha & $12.06 \mathrm{a}$ \\
Monday & 2,599 & $13.41 \mathrm{a}$ & 10343.13 & $24.63 \mathrm{a}$ \\
Tuesday & 2,626 & $13.55 \mathrm{a}$ & 21117.04 & $12.74 \mathrm{a}$ \\
Wednesday & 2,637 & $13.61 \mathrm{a}$ & 10925.89 & $12.12 \mathrm{a}$ \\
Thursday & 2,685 & $13.86 \mathrm{ab}$ & 10390.52 & $14.31 \mathrm{a}$ \\
Friday & 2,779 & $14.34 \mathrm{ab}$ & 12270.96 & $15.26 \mathrm{a}$ \\
Saturday & 2,974 & $15.35 \mathrm{ab}$ & 13074.27 & $08.88 \mathrm{a}$ \\
Sunday & 3,077 & $15.88 \mathrm{~b}$ & 7613.20 & 100.00 \\
\hline Total & 19,377 & 100.00 & 85735.01 & \\
\hline
\end{tabular}

* Means followed by the same letter are not statistically different by the SNK test at 5\% level. 


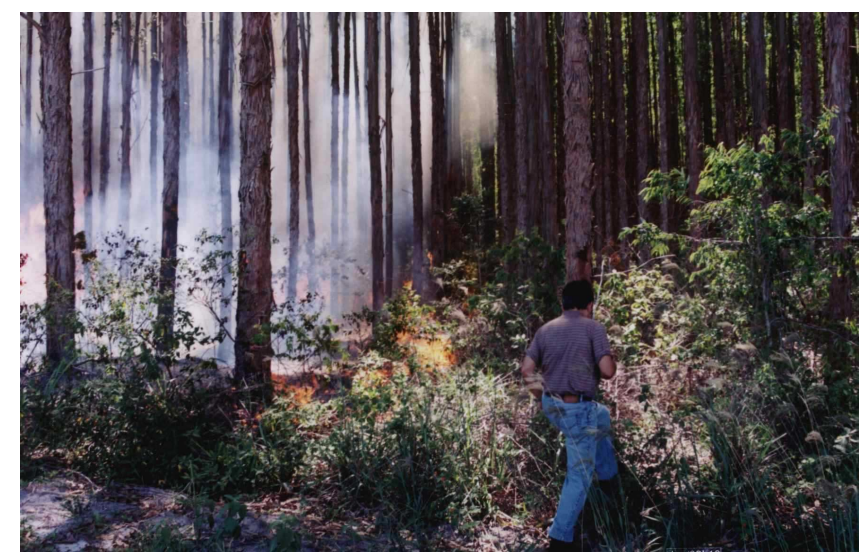

Figure 1. Incendiary caused fire in a eucalyptus plantation.

Figura 1. Incêndio causado por incendiário em uma plantação de eucalipto.

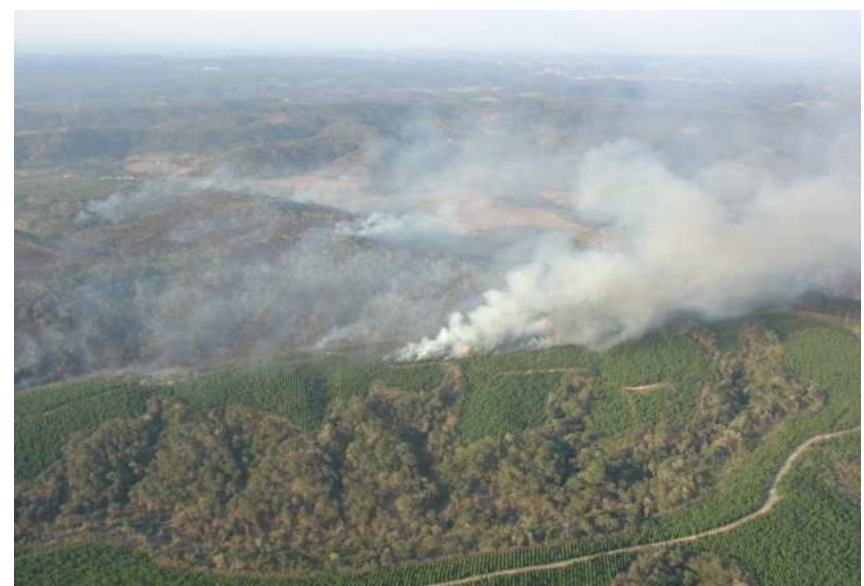

Figure 2. A debris burning caused fire in a pine plantation.

Figura 2. Incêndio causado por queima de limpeza em uma plantação de pinus.

Table 4. Fire occurrences and burned areas by cause group, from 1998 to 2002.

Tabela 4. Ocorrências de incêndios e áreas queimadas por grupo de causa no período 1998-2002.

\begin{tabular}{lcccc}
\hline \multirow{2}{*}{ Cause } & \multicolumn{2}{c}{ Fires } & \multicolumn{2}{c}{ Burned areas } \\
\cline { 2 - 5 } & $\mathbf{n}^{\circ}$ & $\boldsymbol{\%}^{*}$ & ha & $0.38 \mathrm{~d}$ \\
Lightning & 103 & $1.56 \mathrm{c}$ & 70.47 & $23.67 \mathrm{~b}$ \\
Debris burnings & 870 & $13.14 \mathrm{~b}$ & $4,434.33$ & $1.17 \mathrm{~d}$ \\
Smoking & 109 & $1.65 \mathrm{c}$ & 218.48 & $65.34 \mathrm{a}$ \\
Incendiaries & 4,579 & $69.15 \mathrm{a}$ & $12,240.45$ & $0.07 \mathrm{~d}$ \\
Rail road & 7 & $0.11 \mathrm{c}$ & 13.79 & $0.08 \mathrm{~d}$ \\
Recreation & 19 & $0.29 \mathrm{c}$ & 14.56 & $0.79 \mathrm{~d}$ \\
Forest operations & 205 & $3.10 \mathrm{c}$ & 148.49 & $8.51 \mathrm{c}$ \\
Miscellaneous & 730 & $11.02 \mathrm{~b}$ & $1,594.09$ & 100.00 \\
\hline Subtotal & 6,622 & 100.00 & $18,734.66$ & - \\
\hline Undetermined & 12,755 & - & $67,000.36$ & - \\
\hline Total & 19,377 & - & $85,735.02$ & \\
\hline
\end{tabular}

* Means followed by the same letter are not statistically different by the SNK test at $5 \%$ level. 


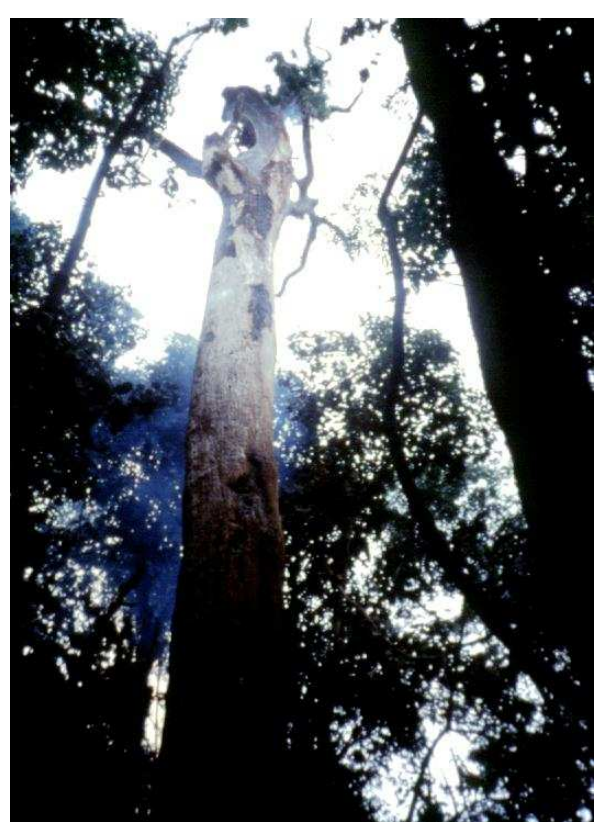

Figure 3. Fire caused by a lightning that stroke a snag in a broadleaf forest. Figura 3. Incêndio causado por um raio que atingiu um toco de peroba.

\section{CONCLUSIONS}

The results obtained in this research allow the following conclusions:

- The fire season in Brazil, in the period 1998-2002, extended from July to October, when almost 60\% of the fires occurred and nearly $90 \%$ of the area was burned.

- Most fires occurred between 1:00 and 4:00 PM and the majority of the area burned was a consequence of the fires that started from 1:00 to 5:00 PM.

- No significant differences were observed in the number of occurrences or in the burned areas, among the days of the week.

- Incendiaries were the leading group of fire occurrences and burned areas, seconded by Debris burning and Miscellaneous in the number of fires and Debris burning in the affected areas.

\section{REFERENCES}

CROSBY, J. S. 1954. Probability of fire occurrence can be predicted. [S.1.]: USDA Forest Service 14 p. (Technical Paper C-S243).

UNITED NATIONS FOOD AND AGRICULTURE ORGNIZATION (FAO). Metodo de lucha conta incendios forestales. Rome, 1954. $131 \mathrm{p}$.

SANTOS, J. F. Estatísticas de incêndios florestais no Brasil no período de 1998 a 2002. 125 f. Dissertação (Mestrado em Engenharia Florestal) - Setor de Ciências Agrárias, Universidade Federal do Paraná, Curitiba, 2004.

SOARES, R. V.; CORDEIRO, L. Análise das causas e épocas de ocorrência de incêndios florestais na região centro-paranaense. Floresta, Curitiba, v. 5, n. 1, p. 46-56, 1974.

SOARES, R. V.. Perfil dos incêndios florestais no Brasil em 1983. Brasil Florestal, Brasília, DF, n. 58, p. 31-42, 1984.

SOARES, R. V. Perfil dos incêndios florestais no Brasil de 1984 a 1987. Floresta, Curitiba, v. 18, n. 1-2, p. 94-121, 1988. 
SOARES, R. V. Forest fires in Brazilian plantations and other protected public land. Proceedings of the...SYMPOSIUM ON FIRE ECOLOGY, 3., 1989, Freiburg . v. 1, p. 5-6.

SOARES, R. V. Arson: a major cause of forest fires., INTERNATIONAL FIRE CONFERENCE. Social Perspectives Section, 2., 1997, Vancouver. Proceedings of the...Vancouver: Canadian Forestry Service, 1997.

SOARES, R. V.; SANTOS, J. F.. Brazilian forest fires statistics in two periods. Rotterdam, Millpress, INTERNATIONAL CONFERENCE ON FOREST FIRE RESEARCH, 4., 202. Proceedings of the... [S.1.: s.n.], 2002a. 1 CD-ROM.

SOARES, R. V.; SANTOS, J. F. Perfil dos incêndios florestais no Brasil de 1994 a 1997. Floresta, Curitiba., v. 32, n. 2, p. 219-232, 2002 b.

STEEL, R. G. D.; TORRIE, J. H. 1960. Principles and procedures of statistics. New York, McGrawHill. $481 \mathrm{p}$. 